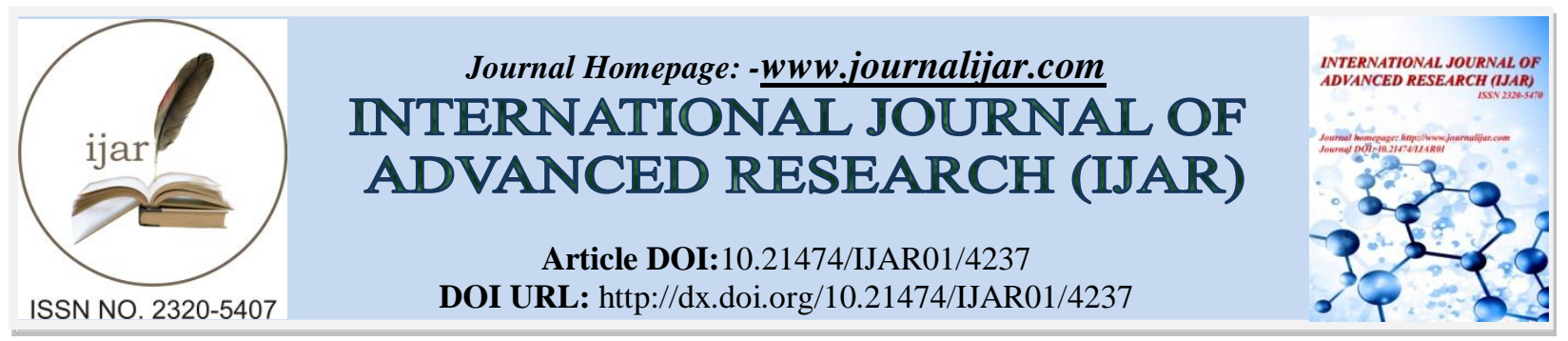

RESEARCH ARTICLE

\title{
STRATEGIES FOR EFFICIENT MANAGEMENT BY SCHOOL MANAGERS AT ELEMENTARY SCHOOLS.
}

Phd. Semir Sejtanic.

University „Dzemal Bijedic“ Mostar, Teacher's faculty.

\section{Manuscript Info}

Manuscript History

Received: 21 March 2017

Final Accepted: 24 April 2017

Published: May 2017

Key words:-

school manager, teachers, strategic

management, efficient management

\section{Abstract}

Changes within education process include improvement of general organization of school's educational practice. Main focus gets redirected from an individual to a conception change, from evaluation of pupil's achievements on to evaluation of school's total results; from the teachers, as subjects of the change, on to school managers, as leaders and bearers of development change. Research has been conducted in southern part of Bosnia and Herzegovina (Herzegovina region), using the sample of 240 examinees (232 teachers and 8 school managers), in order to determine the leading role of a school manager. The results obtained on the basis of standardized instruments show that school managers show flexibility in their work with teachers, and that teachers are involved in the school management process, but are not sufficiently involved in strategic planning and monitoring of school work results. Strategic managers need to apply strategy which they can implement within the organization and that way they show long-term planning, whilst taking into consideration all the circumstances of school work.

Copy Right, IJAR, 2017,. All rights reserved.

\section{Introduction:-}

Improvement of the school work organization includes the restructuring and accepting new ideas and ways of work. The present situation is that schools in the area of Herzegovina Neretva Canton are directed by school boards and managed by school managers. A school board works upon the mandate and it's authorities are such of a directing body, and a school manager has got authorities of a management body and educational manager. The role of school manager in process of accepting and promoting changes and innovations is of a great significance for whole counseling-educational school practice.

School manager's activities are very complex and they represent very important resource for modern schools. They manage school and it's activities via their colleague teachers and direct teachers towards accomplishment of given goals. Management in education represents a certain management skill, which involves certain activity in influencing and directing the work of teachers and other employees, in order to achieve most successful results of organization and whole educational work. Their work is what either success or failure of certain school depends on. Leadership is a process of influence leading to the achievement of desired purposes. Successful leaders develop a vision for their schools based on their personal and professional values. They articulate this vision at every opportunity and influence their staff and other stakeholders to share the vision (Bush and Glover 2003). 
Management work is very complex and responsible. Complexity of management work requires interdisciplinary approach in research process. With regards to that, in accordance with some authors, management duties cover at least four dimensions; i.e. activities or phases of management process, which include planning, organizing, leading and controlling (Baron, 1998 p.205). Efficient management strategy enables the manager to develop techniques by which they will assist the school to develop in all it's disciplines and will make that school such that it's students' learning is at high level and they accomplish high educational goals. Efficient management provides vision, direction and purpose to the changes, and it analyses it's context. Strategic leadership is not a micromanagement strategy; it answers 4 key questions: 1-What (Clear goal and vision), 2-How (Draft the path that employees will follow in order to accomplish the given goals), 3-When (At what time) and 4-Where (at which location). Every school should have a prepared strategy which should be presented to employees, parents and local community. Strategic management covers not only planning and presenting the strategy, but also it's successful realization. Nowadays school managers are responsible for work of larger number of people; from students to school board members, from parents to politicians, from teachers to local entrepreneurs, from the auxiliary staff to the union (Mangin, 2007). In accordance with Notman and Henry (2010) efficient school managers use more leadership strategies to lead teachers, in order to increase the level of students' results: vision and purpose, focus on to students' accomplishments, improvement of school practice, consultation with the teachers and community, employment of quality personnel and powerful management team. A leadership skill that is important for success of a school manager is a decision making skill. When the employees cowork in making decisions, it is an imperative for their leader to make sure that it has been clearly presented how important are the decisions which influence the school (Crum, Sherman and Myran, 2009). Researches referring the efficiency of school management have been directed to various areas; from researches focused on analyses of manager's personality and characteristics (Adair, 1984 towards Armstrong, 2001), over researches directed towards strategies, concepts and management models (Elmore 2000, Fink and Resnick 2001), all the way to researches referring the competencies required for efficient school management (Bueno and Tubbs, 2004; Jokinen, 2005).

Every school is unique and it functions under different conditions, therefore successful realization of leadership function of school manager is preconditioned by various influences of social community. Within such diversity, more successful school managers will be those who have got appropriate professional qualifications, who conduct quality and successful democratic communication and who work on their professional improvement and development; whilst Resman (2001) emphasizes that professional improvement must not be limited only to organizational matters within school management, but also to pedagogic leadership tasks.

Without quality management, the organization will not fulfill it's task. School administration includes coordination and control of work activities of other parties, so that their activities do get completed in a successful and efficient manner (Robbins and others, 2009, p.10). Modern management, as a theory of school management and leadership, offers it's findings in order to accomplish given goals in a more successful and efficient manner. According to Jurić, there are 4 basic management functions within education process: planning, organizing, leading and controlling (Jurić, 2004). Efficient school manager possesses various skills and use them in interpersonal relations; they also influence on making the culture of integrity and they invest a lot into mutual understanding of their employees (Daresh, J.C., Gantner, M.W., Dunlap, K., Hvizdak, M., 2000). The strength of an organization mostly depends on the school manager's management communication and other skills.

\section{Research Methodology:-}

Respecting the contents of theme-related authors' projects and recent tangent explorative researches, we have outlined an empirical non-experimental research, with a goal to explore and analyze the leadership role of a school manager. Making the goal concrete, we have listed the following tasks that were to be realized within this research:

1. To research whether there is a statistically significant difference between the assessments of school managers and those of elementary school teachers, stating that school managers show flexibility in running the schools and dealing with the employees

2. To research whether there is a statistically significant difference between the assessments of school managers and those of elementary school teachers, stating that teachers are involved in the process of school management

3. To determine whether there is a statistically significant difference between the assessments of school managers and those of elementary school teachers, stating that teachers participate in strategic planning and monitoring the school results.

Population from which we extracted the samples of examinees for this research was teachers and school managers of elementary schools located in the southern part of Bosnia and Herzegovina (Herzegovina region). In total, the 
research has included 8 elementary schools (25\% of population) therefore the collected results can be considered representative. Research has included 232 teachers and 8 school managers. Amongst the teachers, 31 of them $(13,36 \%)$ were men and 201 of them $(86,63 \%)$ were women. The professional profiles of examinees as well as the years of experience in work with children are presented in the table no.1.

Table 1:- Examinees' education degree and years of experience.

\begin{tabular}{|l|l|l|l|l|l|}
\hline & \multicolumn{2}{l|}{ Total } \\
\cline { 2 - 6 } & Two year degree & University degree & MR & DR & \\
\hline Teachers & 68 & 142 & 22 & 0 & $\mathbf{2 3 2}$ \\
\hline School managers & 2 & 2 & 3 & 1 & $\mathbf{8}$ \\
\hline & Experience & $11-20$ & $21-30$ & $31-40$ & Total \\
\cline { 2 - 6 } & $0-10$ & 112 & 47 & 4 & $\mathbf{2 3 2}$ \\
\hline Teachers & 69 & 7 & 1 & 0 & $\mathbf{8}$ \\
\hline School managers & 0 & & & \\
\hline
\end{tabular}

For the needs of this research, we have constructed the scale, identical for teachers and school managers. The scale is "Likert" type and is composed of three parts. The first part has questioned the leading of school, second part referred to strategic planning and achievement monitoring, and the third part referred to school management. Examinees (teachers and school managers) have assessed the frequency of certain appearances (using the terms "always", "often", "sometimes", "rarely" and "never"). Using the statistics program SPSS 23 we have defined the reliability $r=.942$ (Cronbach alpha coefficient). Discrimination of the thesis was calculated by the item-total correlation i.e. via correlation between the results achieved by the examinees at certain thesis and the results achieved at the entire assessment. All the assessments whose correlations are of significance do contribute to the assessment, and do express a satisfying discrimination. Final version of the scale shows distribution which significantly devise from normal distribution, which has been confirmed by Colmogorov Smirnov test, that states that $\mathrm{D}=.61, \mathrm{df}=202, \mathrm{p}=.000$ i.e. as well as the Shapiro-Wilk test which states that $\mathrm{D}=.903, \mathrm{df}=202, \mathrm{p}=.000$. Collected results have been statistically processed within SPSS 23 program and have been presented by both table and a graph. Differences between the assessments of teachers and those of school managers have been defined by $\chi 2$ test (Phi square test) whereat the statistically significant difference begins at level of significance up to 0.05 $(\mathrm{p} \leq 0.05)$.

\section{Results of Researches and Discussions:- School leadership:-}

School managers lead the schools and take the roles of leaders whose goal is to motivate the employees so that they achieve better results. In order to lead the school as good as possible, school managers must possess competencies needed to be able to observe and analyze situation in the school and act towards improvement of work results. Apart from self-confidence that school manager needs to have, it is very important that they have communicational competencies which allow them to lead school in a proper manner, resulting with satisfaction of employees and the social community that school is located in. With their vision and enthusiasm, they direct and motivate the teachers to achieve as good as possible school results. In accordance with given task, we have researched how involved the teachers are in the process of school leadership and how much the school managers motivate and maintain good cooperation with the teachers. 


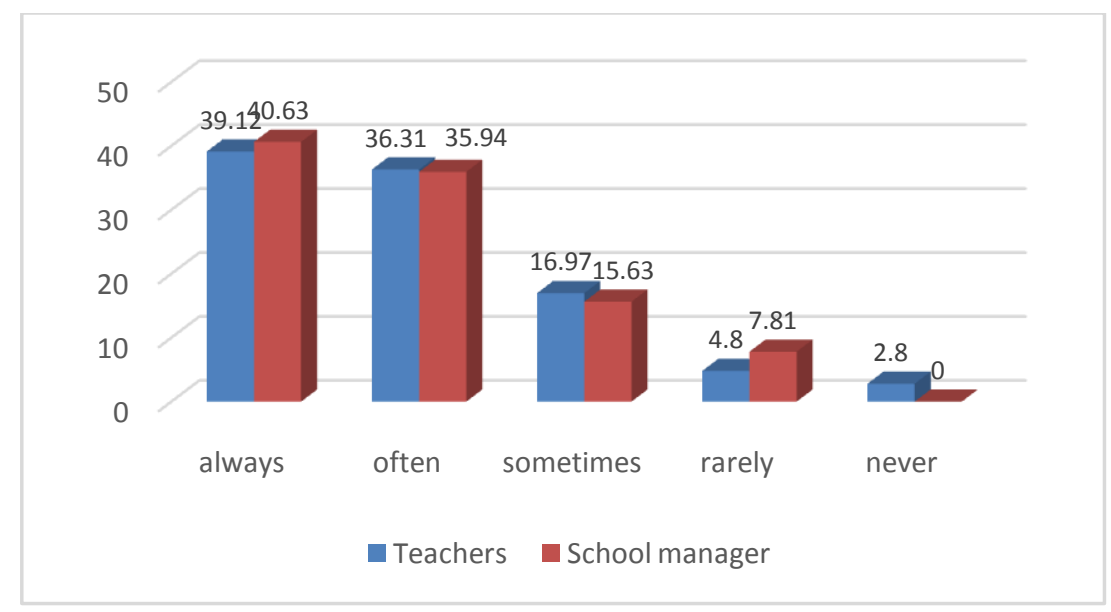

Graph 1:-Involvement of teachers in the leadership process

The aforementioned results show the way that examines assess the leader's role of school manager as satisfying at all offered measures. School managers understand the importance of the position they hold and the way they present the work of school within social community. The teachers have recognized the intention of school managers referring to the area of teachers' professional improvement and development of democratic communication and quality interpersonal relations. Examinees have given their assessments on high level of participation of teachers in communication and positive interpersonal relations, and high level of motivation by school managers towards teachers, referring to achievement of a common goal.

Table 2:-School manager's leadership at schools.

\begin{tabular}{|l|c|c|c|c|c|}
\hline Examinee & $\mathrm{N}$ & Mean & Std. Deviation & Min & Max \\
\hline Teachers & 232 & 1,95 & 0,69 & 1 & 5 \\
\hline School manager & 8 & 1,9 & 0,46 & 1,37 & 2,87 \\
\hline
\end{tabular}

Result of Phi square $\chi^{2} 3,04$ does not go over border value at level $0,05 \chi^{2} 11,1$, which indicates that there is no statistically significant difference between perception of teachers and those of school managers; therefore we hereby can confirm the first hypothesis of our research. School leadership is focused on improvement of teachers' work as well as their development, so they can achieve their full working potentials. A school manager, who strikes for quality work and quality leadership shall be a role model for the teachers, shall listen carefully his/her colleague teachers and shall respect their opinions. That way they will develop a cooperative and positive atmosphere at the school.

\section{Strategic Planning:-}

Strategic planning at schools commence when the school managers, due to various motives, start thinking in strategic and critical manner, in order to improve their own work and work of the teachers, via various types of innovative work. Providing a motivational environment for the sake of professional development of all teachers is a precondition for the school to become a place where at the teachers can express all of their potentials in the best possible way; and whereat students can achieve the best educational results. Very important segment of strategic planning is for school managers to get clear vision and mission of the institution they lead, to include teachers in creation of school strategic plans and to convince teachers to accept changes which will lead to increase of work quality. Strategic planning is a process which describes how the given goals shall be met, as well as which resources are necessary for the school goal to be met. 


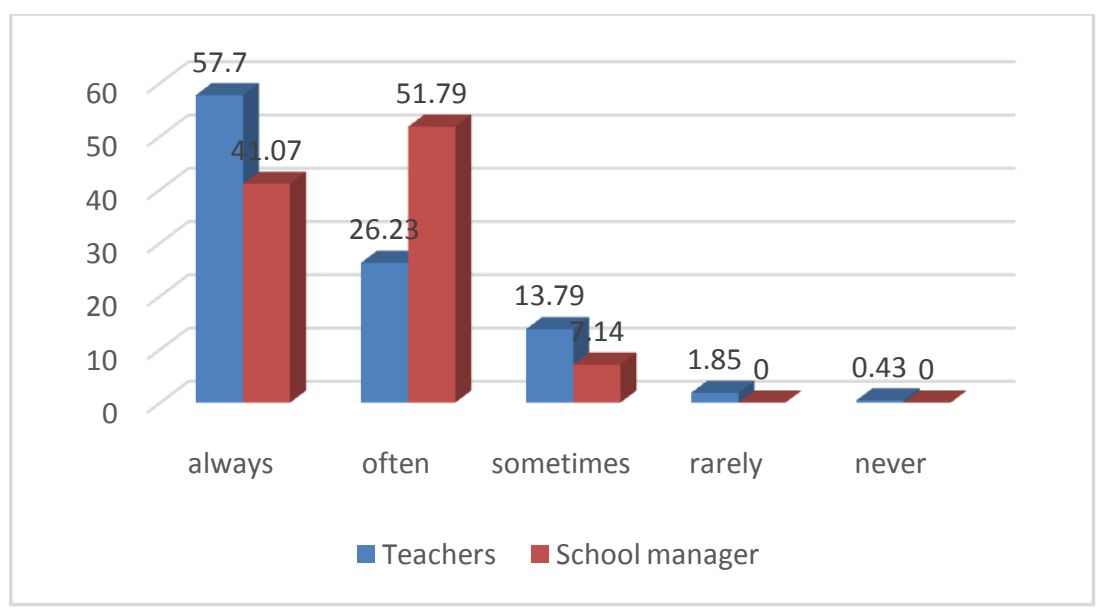

Graph 2:-Involvement of teachers in strategic planning

Our research has shown, on the basis of examinees' assessments, that teachers are greatly involved in the process of strategic planning and monitoring the school achievements. Strategic planning at schools is a complex process that involves all the participants of school life, and requires detailed procedures and organized team work. The research has shown that teachers are involved in strategic planning and monitoring the school results, as well as that school managers do motivate teachers to be involved. Results of analyzing the collected data have shown that school priorities, in most cases, are to have constant improvement of the employees, good equipment of school means, good cooperation with parents and other social partners, as well as to initiate changes that lead to work improvement, and for school managers to motivate teachers to participate in aforementioned processes.

Table 3:-Strategic planning and monitoring the school achievements

\begin{tabular}{|l|c|c|c|c|c|}
\hline Examinee & $\mathrm{N}$ & Mean & Std. Deviation & Min & Max \\
\hline Teachers & 232 & 1,61 & 0,68 & 1 & 4,22 \\
\hline School manager & 8 & 1,66 & 0,42 & 1 & 2,28 \\
\hline
\end{tabular}

Both idea and practice of learning change during the process of strategic planning. This creates a need for openness and constant readiness to adopt and apply new knowledge, skills and competencies, during whole life. Obtained value $\chi^{2} 18,71$ does go over border value at level $0,05 \chi^{2} 11,1$ which shows that there is a statistically significant difference between assessments of school managers and those of elementary school teachers on whether the teachers participate in strategic planning and monitoring the school achievements. Although great number of teachers stated to have participated in strategic planning of school work, the value of $\chi 2$ test points out that we can reject our second hypothesis. Strategic planning is an asset for better direction of the organization, greater flexibility and better coordination of work. School managers are in charge of strategic planning, i.e. definition of strategic goals and plans, because they can, the best way possible, monitor and recognize the problems on the level of whole organization. Strategic planning pleads for the school managers to formulate strategy and bear greatest responsibility, but it also includes the teachers. Collected results point out that teachers are involved by school managers, but not as much as they think it is necessary.

\section{Process of school Management:-}

School manager plays a constant role of a leader and an organizer of education process and therefore it is very important for them to be well trained in the field of interpersonal relations and management. One of important roles of school manager is certainly to develop positive atmosphere amongst the employees. Using quality communication skills and techniques, school managers are to solve possible conflict situations during every day work. They need to be good motivators and make their own positive example to lead the employees in order to create positive working climate, as a precondition for better work results. Our research covered 2 types of school management: authoritative and flexible. 
Table 4:-Management process

\begin{tabular}{|c|c|c|c|c|c|c|c|c|c|c|c|c|}
\hline \multirow{2}{*}{$\begin{array}{l}\text { Proces } \\
\text { rukovođenja }\end{array}$} & \multirow[t]{2}{*}{ Examinee } & \multicolumn{2}{|c|}{ always } & \multicolumn{2}{|c|}{ often } & \multicolumn{2}{|c|}{ sometimes } & \multicolumn{2}{|c|}{ rarely } & \multicolumn{2}{|c|}{ never } & \multirow{2}{*}{ స్త్ర } \\
\hline & & $\mathrm{f}$ & $\%$ & $\mathrm{f}$ & $\%$ & $f$ & $\%$ & $\mathrm{f}$ & $\%$ & $f$ & $\%$ & \\
\hline \multirow[t]{2}{*}{ Authoritative } & $\mathrm{T}$ & 209 & 18,01 & 327 & 28,19 & 210 & 18,10 & 182 & 15,69 & 232 & 20,38 & 1160 \\
\hline & SM & 7 & 17,50 & 11 & 27,50 & 4 & 10,00 & 14 & 35,02 & 4 & 10,00 & 40 \\
\hline \multirow[t]{2}{*}{ Flexibility } & $\mathrm{T}$ & 498 & 26,83 & 556 & 29,96 & 434 & 23,38 & 267 & 14,39 & 101 & 5,44 & 1856 \\
\hline & SM & 17 & 26,56 & 24 & 37,50 & 9 & 14,06 & 12 & 18,75 & 2 & 0,11 & 64 \\
\hline
\end{tabular}

Legend: T-Teachers, SM- School manager

Descriptive indicators of the scale assessing the school manager's management role at school, which refer to manager's flexibility and authority shown during the process of school management, have been presented as average values at formed sub-scales. Collected results show that school managers are aware of their management role as well as their responsible position within society, thus they show flexibility during the process of management.

Table 5:-School managers' management role at schools

\begin{tabular}{|l|l|c|c|}
\hline Examinee & Authoritative & Flexibility \\
\hline \multirow{4}{*}{ Teachers } & $\mathbf{N}$ & 232 & 232 \\
\cline { 2 - 4 } & Mean & 3,56 & 3,41 \\
\cline { 2 - 4 } & Std. Deviation & 0,53 & 0,56 \\
\cline { 2 - 4 } & Min & 1,4 & 1,2 \\
\cline { 2 - 4 } & Max & 3,8 & 3,8 \\
\hline \multirow{5}{*}{ School manager } & $\mathbf{N}$ & 8 & 8 \\
\cline { 2 - 4 } & Mean & 2,32 & 0,34 \\
\cline { 2 - 4 } & Std. Deviation & 0,36 & 1,62 \\
\cline { 2 - 4 } & Min & 1,8 & 3,12 \\
\cline { 2 - 4 } & Max & 3 & \\
\hline
\end{tabular}

In accordance with the assessment of school managers and teachers, calculated value of $\chi^{2}$ test for "authoritative school management" thesis is $\chi 23,19$ and for "flexible school management" thesis is $\chi 24,92$, which does not go over the border value at level $0,05 \chi^{2} 11,1$. On the basis of that, we can conclude that there is no statistically significant difference between the assessment of school managers and those made by teachers, referring to school management. Our third hypothesis that there is no statistically significant difference between assessments made by school managers and those made by elementary school teachers on whether school managers show flexibility in school management and their attitude towards the employees can be completely confirmed. Research has shown that the examinees are mostly satisfied with realization of school managers' management role at schools in the area of Herzegovina-Neretva Canton and they monitor the mentioned role through flexibility and authority shown during it's implementation. Collected indicators, based on the results of this research, direct us to a quality and flexible management role of a school manager, which does not exclude the need for further and continuous professional improvement of school managers. Successful school manager must, at the same time, take over the roles of a planner, and expert, an adviser, a motivator, an organizer and an implementer of numerous school activities. During the process of school management, it is necessary for a quality school manager to adjust goals and tasks of the school with personal goals and interests of the employees.

\section{Conclusion:-}

Even though the school manager position sometimes brings certain power and sometimes even an opportunity to misuse that power, it is very important for the manager to know that the position does not give them a right to be directive, arrogant or to try by all means to change their colleagues the way they think is right. Flexible approach of the manager opens more possibilities for respect of differences between employees, as well as the respect of interpersonal relations. The research has shown that school managers are more satisfied by their role realization than the teachers are. It is necessary for a modern school manager to build their reputation and position at school on the basis of their competencies, professional and pedagogic experience, and communication skills as well as moral and human qualities. Research has shown that teachers are satisfied by school management processes and flexibility of school managers at schools in the area of southern part of Bosnia and Herzegovina (Herzegovina region), however they think it is necessary to have the teachers involved more in the strategic planning of school work. Every school manager needs to develop a working context that is supported by professional culture of tolerance, cooperation, compromise and care for others. As the first amongst the equal ones, it is necessary to try, as much as possible, to 
involve all teachers into the decision making process and give them certain tasks, but at the same time increase their responsibility at work. That will, at the final line, increase the efficiency of school and bring the results up to a higher level.

\section{Reference:-}

1. Armstrong, M. ( 2001).Kompletna menadžerska znanja. Zagreb: M.E.P. Consult

2. Baron, R.A. ( 1998 ). Ponašanje u organizacijama. Beograd: Želnid

3. Bueno, C and S. Tubbs (2004). Identifying global leadership competencies: An exploratory study. The Journal of American Academy of Business. Cambridge,: September, 2004, 80-87.

4. Bush. T. and D. Glover (2003). School Leadership: Concepts and Evidence. National College for School Leadership

5. Crum, K. S., Sherman, W. H., \& Myran, S. (2009). Best practices of successful elementary school leaders. Journal of Educational Administration. 48(1), 48-63. http://dx.doi.org/10.1108/09578231011015412

6. Daresh J. C., Gantner M. W., Dunlap K., Hvizdak M. (2000). Words from "the trenches:" Principals' perspectives on effective school leadership characteristics. Journal of School Leadership, 10, 69-83.

7. Elmore, R. (2000). Building a new structure for school leadership. Washington, DC: The Albert Shanker Institute.

8. Fink, E., \& Resnick, L. (2001). Developing principals as instructional leaders. Phi Delta Kappan, 82, 598-606.

9. Jokinen,T. (2005). "Global leadership competencies: a review and discussion", Journal of European Industrial Training, Vol. 29 Issue: 3, pp.199-216, doi: 10.1108/03090590510591085

10. Jurić, V. (2004). Pedagoški menadžment - refleksija opće ideje o upravljanju, Pedagogijska istraživanja. 1 (1): $137-148$.

11. Mangin, M.M. (2007). "Facilitating elementary principals' support for instructional teacher leadership", Educational Administration Quarterly, Vol. 43 No. 3, pp. 319-57

12. Notman, R., \& Henry, A. D. (2010). Building and sustaining successful school leadership in New Zealand. Leadership and Policy in Schools, 10(4), 375-394. http://dx.doi.org/10.1080/15700763.2011.610555

13. Resman, M. (2001). Ravnatelj, vizija škole i motivacija učitelja za sudjelovanje. U: Silov, M. (ur.), Suvremeno upravljanje i rukovođenje u školskom sustavu. Velika Gorica: Persona, $51-80$.

14. Robbins, S, Bergman, R, Stagg, I \& Coulter, (2009). Management, 5th edn, Australia: Pearson Education Australia. 